\section{Ancient DNA and island endemics}

SIR - Most recently extinct and currently endangered species of birds are inhabitants of islands, where the effects of anthropogenic predation and habitat modification have been most severe ${ }^{1}$. Recently, palaeontological records have shown that the effect of prehistoric humans on insular biotas, particularly in the Pacific, were far more severe than previously believed ${ }^{2-4}$, and that many extant flighted bird species that now appear to be endemic to single islands were previously more widespread $^{4}$. Here we report that the combination of ancient DNA and palaeontological techniques can provide information necessary for conservation management of such a species, the endangered Laysan duck (Anas laysanensis).

The Laysan duck is historically known only from the remote, small (370-hectare) island of Laysan in the northwestern Hawaiian chain, where its numbers have varied between 20 and approximately 500 over the past 70 years ${ }^{5,6}$. Fewer than 150 survived drought conditions in 1993, illustrating the vulnerability of this population.

Both the Laysan duck and the Hawaiian duck, or koloa (Anas wyvilliana), were once thought to be derived from stray either (J.R., unpublished data). duck. migratory mallards (Anas platyrhynchos), a perception that has greatly influenced the recovery programme of the Laysan duck $^{7,8}$. However, the relationships between the three taxa were uncertain ${ }^{7,9}$. Recent genetic studies have demonstrated that, while the koloa is indeed closely related to mallards, the Laysan duck is very distinct from

Bones of small ducks occur in Late Pleistocene and Holocene deposits in the chief Hawaiian islands ${ }^{3,10}$. Measurements of the lengths of the main long bones, with sample sizes between 3 and 27, showed the average lengths of the palaeontological specimens to be intermediate between Laysan ducks and koloa (dns). The bones could not be identified from these data because: (1) skeletal morphology is poorly diagnostic in dabbling ducks'; (2) other island ducks changed size during the Holocene ${ }^{11}$; and (3) the bones could represent an extinct taxon distinct from either the koloa or Laysan

To resolve the identity of the subfossil duck bones, we used PCR (polymerase chain reaction) and ancient DNA techniques $^{12}$ to extract and sequence DNA

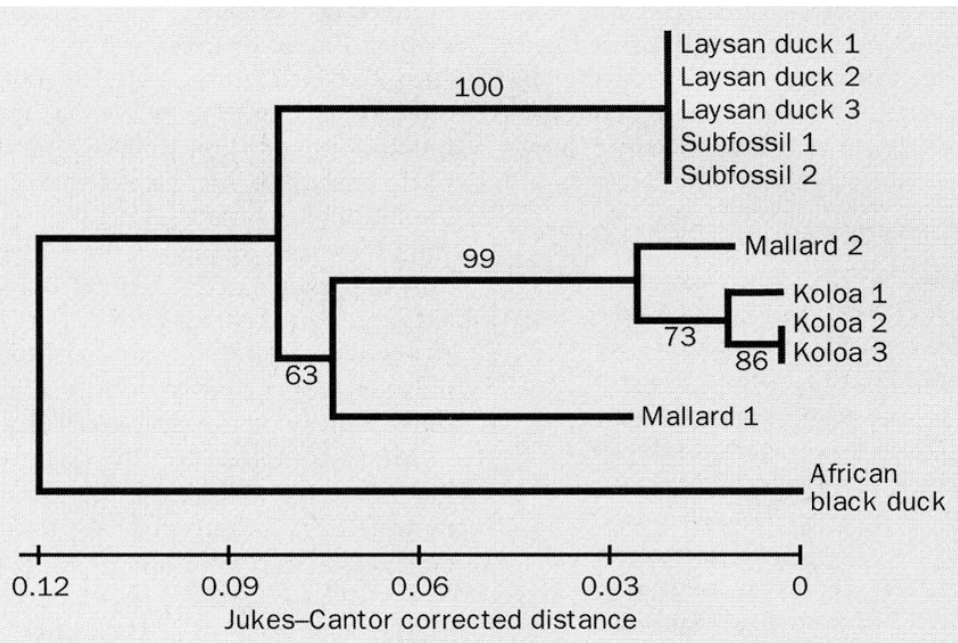

Neighbour-joining two-parameter-corrected distance tree obtained with MEGA ${ }^{13}$. An identical topology is produced by parsimony analysis, with a consistency index of 0.9 (PAUP 3.1.1; ref. 14), and bootstrap values from 1,000 replications are given. The control region sequences were amplified with PCR using primers: C1 ( $L$ O0078) 5'-GTTATTTGGTTATGCATATCGTG; C1R2 (H 00390) 5'-CGATTAGTAAATCCATCTGGTAC; C2 (L 00736) 5'ATCTAAGCCTGGACACACCTG; t-Phe (H 01251) 5'-TGGCAGCTTCAGTGCCATGC; and GCDR ( $L$ 01117) 5'-TATTAGAGAAACTCCAGTAC, where the strand designation and $3^{\prime}$ position in the published chicken sequence are given in parentheses. Sequences were obtained as described ${ }^{12}$ from an African black duck outgroup, two subfossils from different caves on Hawaii, and three koloa, three Laysan ducks and two genetically divergent mallards. Considerable genetic diversity has been detected within mallard taxa (J.R., unpublished data), so the two most divergent haplotypes are used in this analysis. The subfossil sequences were extracted and amplified in Washington DC, in a dedicated laboratory in a remote building, before studies were carried out in both DC and South Carolina on extant taxa. There were 366 homologous positions for all taxa, and 36 variable sites within the ingroups. The subfossil sequences clearly group with the Laysan duck, and are genetically distant from the koloa and mallards. from two variable portions of the mitochondrial control region (133 and 312 base pairs, respectively). Comparison of the sequences (see figure) clearly shows that the subfossil bones match those of the extant Laysan duck, indicating that the species was formerly widespread in the Hawaiian islands.

Late Holocene subfossils of Laysan ducks, including some bones of non-flying juveniles, have been found in habitats varying from near sea level on the islands of Molokai, Oahu and Kauai to formerly forested areas at high elevations (60-1,800 $\mathrm{m})$, far from permanent water, on Maui and Hawaii. Although the species was evidently widely adaptable, it is highly unlikely that Laysan island (maximum altitude $12 \mathrm{~m}$ ) presents an optimal habitat for it.

The disappearance of the Laysan duck everywhere but on Laysan island is assumed to result from the same humaninduced factors (hunting, habitat destruction, introduction of predators and pathogens) that are blamed for the extinction of other taxa native to Pacific islands. Our data justify the reintroduction of the Laysan duck to parts of its former range in the main Hawaiian islands where adverse factors can be controlled. This study demonstrates the value of using ancient DNA and palaeontological information to design recovery plans for endangered species and should provide a model that can be adapted to many other threatened insular species in the Pacific and elsewhere.

\section{Alan Cooper* \\ Judith Rhymer ${ }^{\dagger}$ \\ Helen F. James ${ }^{\ddagger}$ \\ Storrs L. Olson ${ }^{\ddagger}$ \\ Carl E. McIntosh* \\ Michael D. Sorenson* \\ Robert C. Fleischer*}

* Molecular Genetics Laboratory,

National Zoological Park,

Smithsonian Institution,

Washington, DC 20008, USA

tDepartment of Biological Sciences,

Clemson University,

Clemson, South Carolina 29634, USA

fDepartment of Vertebrate Zoology,

National Museum of Natural History,

Smithsonian Institution,

Washington, DC 20560, USA

1. Milberg, P. \& Tyrberg, T. Ecography 16, 229-250 (1993)

2. James, H. F. \& Olson, S. L. Ornith. Monogr. 45, Pt II. (Am. Ornith. Un., Washington DC, 1991).

3. Olson, S. L. \& James, H. F. Ornith. Monogr. 44, Pt I (Am Ornith. Un., Washington DC, 1991)

4. Steadman, D. Science 267, 1123-1131 (1995)

5. Warner, R. E. Condor 65, 3-23 (1963).

6. Marshall, A. P. Bird Conserv. Int. 2, 239-251 (1994).

7. Weller, M. W. The Island Waterfowl (lowa State Univ. Press, Ames, 1980)

8. Moulton, D. W. \& Weller, M. W. Condor 86, 105-117 (1984)

9. Livezey, B. C. Wildfow/ 44, 75-100 (1993).

10. Giffin, J. G. 'Elepaio 35, 1-3 (1993).

11. Worthy, T. H. J. Zool. 215, 619-628 (1988)

12. Cooper, A. in Ancient DNA (eds Herrmann, B. \& Hummel, S.) 149-165 (Springer, New York, 1993).

13. Kumar, S., Tamura, K. \& Nei, M. MEGA: Version 1.01 (Pennsylvania St. Univ., 1993)

14. Swofford, D. PAUP: Version 3.1.1 (Illinois Nat. Hist. Survey, Champaign, 1993). 